\title{
EXERTIONAL SYNCOPE IN A 38 YEARS OLD MAN
}

\section{General Medicine \\ Prof (Dr). Ashis Kumar Saha*}

Professor \& Head in Internal Medicine, MGM Medical College \& LSK Hospital, Kishanganj, Bihar, India. *Corresponding Author

\begin{abstract}
Cardiac myxoma is rare but the most common primary cardiac tumor amongst all cardiac tumors, and left atrial origin is nearly $80 \%$. It is responsible for different constitutional symptoms, progressive dyspnea, and systemic embolization. In this report 38 years patients was admitted with exertional syncope, In investigation transthoracic echocardiography demonstrated large left atrial mass encroaching into left ventricle. The mass after operation was diagnosed as myxoma. This diagnosis is very important from the patient point of view as in undiagnosed may be the forerunner of systemic embolization in different parts of the body.
\end{abstract}

\section{KEYWORDS}

\section{CASE REPORT:}

38 years old security guard came in emergency with history of sudden one episode of Exertional syncope which he never faced before. He told that while he ran upstairs for some work he felt dizziness and fell on the stairs and other colleague caught hold him. There was occasional history of cough with mucoid expectoration but without ant syncope, no history of posture or any straining related syncope, no history of paroxysmal nocturnal dyspnea.

On examination, patient was afebrile having vital signs and jugular venous pressure within normal limit and oxygen saturation in room air was $97 \%$. On auscultation of cardiovascular system, loud first heart sound in mitral area with suspected tumor plop but in supine position there was no murmur. But in standing position there was evidence of mid diastolic murmur in mitral area. Auscultation of chest demonstrated normal vesicular breath sound but no added sound. No evidence of chronic heart failure, like, pedal edema, positive hepatojugular reflux seen.

On laboratory investigation, all hematological and biochemical parameters were normal. Echocardiography demonstrated large $4.9 \mathrm{x}$ $4.8 \mathrm{~cm}^{2}$ mass in the left atrium encroaching into left ventricle. Left ventricular ejection fraction is $60 \%$. Left atrium is moderately enlarged (Fig 1).

After preanesthetic check-up he underwent cardiothoracic surgery to remove the left atrial mass which was diagnosed histologically as myxoma. During removal it was seen that this tumor was attached to left atrial septum. Patient was discharged after $7^{\text {th }}$ day postoperatively with following medications, like, vitamins, aspirin. After two weeks repeat transthoracic echocardiography was performed to see the function of the heart which was shown as normal (Fig 2).

Figure 1

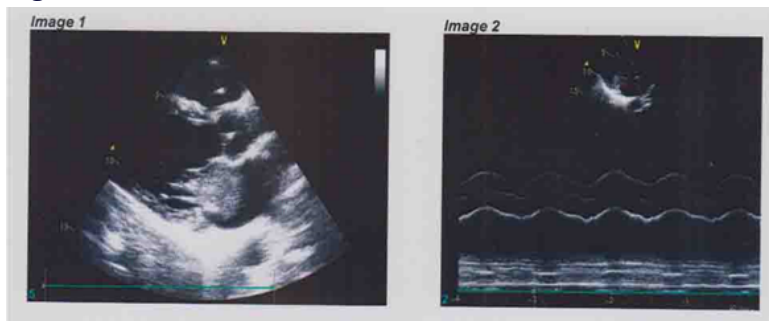

Fig:2

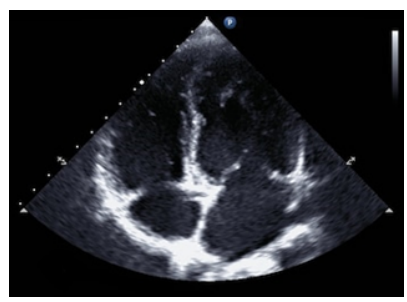

\section{DISCUSSION:}

Atrial myxoma accounts for $0.1 \%$ population in the world $1.80 \%$ of primary cardiac tumor is benign, of these half are benign tumor is atrial myxoma, papillary fibroelastoma and lipoma are the rest in adult and rhabdomyoma and fibroma in child ${ }^{2,3}$. Approximately $80 \%$ to $90 \%$ of myxoma is seen in left atrium, nearly $12 \%$ to $15 \%$ in right atrium and rarely from ventricles ${ }^{4,5,6}$. This tumor tissue is composed of mucopolysaccaride tissue containing scattering of cells ${ }^{7}$. This is common in females ${ }^{4}$.

Symptoms of tumor depends upon several factors, like, location of tumor, amount of obstruction of blood flow through the heart, embolization, invasion to the surrounding lung and myocardium along with constitutional symptoms. Systemic embolization is very common in case of left atrial and aortic myxoma ${ }^{8}$. Depending upon the position of the tumor different types of conduction abnormalities, hypertrophy of left atrium, heart failure and syncope may occur. Most common manifestations of atrial myxoma are fatigue, weight loss with cardiovascular features, like, Exertional dyspnea, paroxysmal nocturnal dyspnea, orthopnea, tumor embolization of in cerebral blood vessels leading to infarction producing neurodeficit. ${ }^{90.11 .12}$. This embolization may also produces retinal artery occlusion even sudden death $^{13,14}$. In this case the clinical findings of loud first heart sound and early diastolic sound, tumor plop due to progress of the myxoma into the left ventricle from left atrium. The syncopal attack was due to obstruction of blood flow from left atrium to left ventricle thereby peripherally to the cerebral vessels by the myxoma which is more common in upright position.

Use of postoperative anticoagulation treatment after successful removal of left atrial myxoma is not demonstrated. But there are many case reports in case of removal of right atrial myxoma producing pulmonary embolism as there was incidence of $0.4 \%$ to $5 \%$ incidence of pulmonary embolism by the fragment of operated tissue during removal of tumor or incomplete surgical resection ${ }^{1}$. This recurrence is due to friability of the tumor tissue and easily detachability from the origin. Usually there is incidence of recurrent embolism from many causes, like, emboli of multiple origin, family history of myxoma (Carney complex) or recurrences from progenitor cells ${ }^{1,15}$. Carney complex consists of pigmentation in the skin called lentigines, multiple myxomatous tumor in the heart as well as throughout the body and tumors in the multiple endocrine glands ${ }^{16}$. This complex ids responsible for $7 \%$ to $10 \%$ of cardiac myxoma and recurrence rate is $\operatorname{high}^{17,18}$.

\section{CONCLUSION:}

Though cardiac tumor is rare but common cardiac tumor is cardiac myxoma. In absence of any constitutional symptom presentation of exertional syncope must require clinical examination of heart with concurrent echocardiography to exclude primary cardiac tumor to prevent future systemic tomor embolization.

\section{REFERENCES:}

1. Jung J, Hong YS, Lee CJ, Lim SH, Choi H, Lee S. Successful surgical treatment of right atrial myxoma complicated by pulmonary embolism. Korean J Thoracic Cardiovase Sur. 2013:46:63-67. 
2. Molina JE, Edwards JE, Ward HB,. Primary cardiac tumors: Experience at the University of Minnesota. Thoracic Cardiovasc Sur. 1990;38(2):183-191.

3. Ying L, Lin R, Gao Z, Qi J, Zhang Z, Gu W. Primary cardiac tumors in children: a center's experience. J Cardiovasc Surg. 2016; 11:52.

4. Salcedo EE, Cohen GI, White RD, Davison M. Cardiac tumors: diagnosis and management. Carr Probl Cardiol. 1992; 17:73-133.

5. Vander Salm TJ. Unusual primary tumors of the heart. Semin Thorac Cardiovasc Surg. 2000;12:89-100

6. Susupaus A, Foofuengmonkolkit K. Bilateral atrial myxoma: a case report. J Med Assos Thai. 2016;99(2):S216-S219

7. Pucci A, Gagliardotto P, Zanini C, Pansini S, di Summa M, Mollo F. Histopathologic and clinical characterization of cardiac myxoma: review of 53 cases from A single institution. Am Heart J. 2000;140:134-138.

8. Elbardissi AW, Dearani JA, Daly RC, et al. Embolic potential of cardiac tumors and Elbardissi AW, Dearani JA, Daly RC, et al. Embolic potential of ca
outcome after resection: a case-control study. Stroke. 2009;40:156-162

9. Pinede L, Duhaut P, Loire R. Clinical presentation of left atrial cardiac myxoma. A series of 112 consecutive cases. Medicine (Baltimore). 2001;80:159-172.

10. Streker T, Agaimy A. Giant left atrial myxoma causing drop attacks by prolapsing into mitral valve. Int J Clin Exp Pathol. 2012;5:996-999.

11. Sabageh D, Odujoko OO, Komolafe AO. Right atrial myxoma as a possible cause of hemorrhagic stroke and sudden death. Niger Med J. 2012;53:102-104.

12. De Almeida LA, Hueb JC, de Moraes Silva MA, Bazan R, Estrozi B, Raffin CN Cerebral ischemia as neurological manifestation of atrial myxoma: case report. Neuropsiquiatr. 2006;64(3A):660-663.

13. Yu Y, Zhu Y, Dong A, Su Z. Retinal artery occlusion as the manifestation of left atrial myxoma: a case report. BMC Ophthalmol. 2014;14:164

14. Rajani AR, Muaz RN, Govindaswamy PR, Mian AH. Arrhythmias are not to blame for all cardiac syncope patients: left atrial myxoma causing syncope in a middle-aged man. BMJ case Rep. 2015;2015.

15. Shinfeld A, Katsumata T, Westaby S. Recurrent cardiac myxoma: myxoma seeding or multifocal disease? Ann Thorac Surg. 1998;66:285-288.

16. Carney JA. Difference between nonfamilial and familial cardiac myxoma. Am J Surg Pathol. 1985;9:53-55.

17. Hermans K, Jaarsma W, Plokker HW, Cramer MJ, Morshuis WJ. Four cardiac myxomas diagnosed three times in one patient. Eur J Echocardiog. 2003;4:336-338.

18. McGowan AR, Thibodeau C, McGowan A. Intracranial and visceral arterial embolization of a cardiac myxoma that was treated with endovascular stent-retriever therapy. Interv Neuroradiol. 2016;22:535-539. 